\title{
Upper Bound for Energy Efficiency in Multi-Cell Fibre-Wireless Access Systems
}

\author{
Koonen, A. M. J.; Popov, M.; Wessing, Henrik
}

Publication date:

2013

Document Version

Publisher's PDF, also known as Version of record

Link back to DTU Orbit

Citation (APA):

Koonen, A. M. J., Popov, M., \& Wessing, H. (2013). Upper Bound for Energy Efficiency in Multi-Cell FibreWireless Access Systems. Poster session presented at 39th European Conference and Exhibition on Optical Communication (ECOC 2013), London, United Kingdom.

\section{General rights}

Copyright and moral rights for the publications made accessible in the public portal are retained by the authors and/or other copyright owners and it is a condition of accessing publications that users recognise and abide by the legal requirements associated with these rights.

- Users may download and print one copy of any publication from the public portal for the purpose of private study or research.

- You may not further distribute the material or use it for any profit-making activity or commercial gain

- You may freely distribute the URL identifying the publication in the public portal

If you believe that this document breaches copyright please contact us providing details, and we will remove access to the work immediately and investigate your claim. 


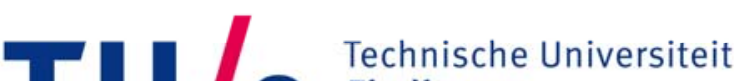

\section{Upper Bound for Energy Efficiency in Multi-Cell Fibre-Wireless Access Systems}

A.M.J. Koonen ${ }^{1}$, M. Popov ${ }^{2}$, H. Wessing ${ }^{3}$

${ }^{1}$ COBRA Institute, Eindhoven Univ. of Technology, Eindhoven, The Netherlands; a.m.j.koonen@tue.nl

${ }^{2}$ ACREO Swedish ICT AB, Kista, Sweden; mikhail.popov@acreo.se

${ }^{3}$ DTU Fotonik, Techn. Univ. of Denmark, Lyngby, Denmark; hewe@fotonik.dtu.dk

Abstract Bringing radio access points closer to the end-users improves radio energy efficiency. However, taking into account both the radio and the optical parts of a fibre-wireless access system, the overall system energy efficiency has an upper bound determined by the relation between the energy consumption of the optical and wireless parts.

Fibre-fed LTE access

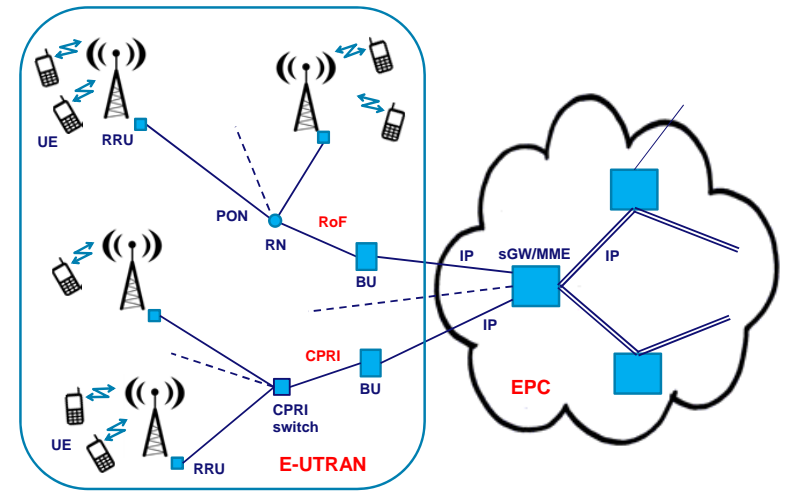

Wired/wireless converged indoor network

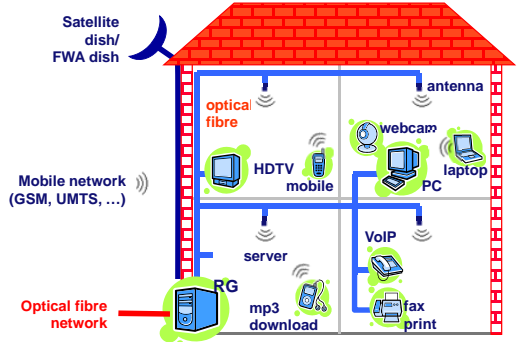

Single large radio cell

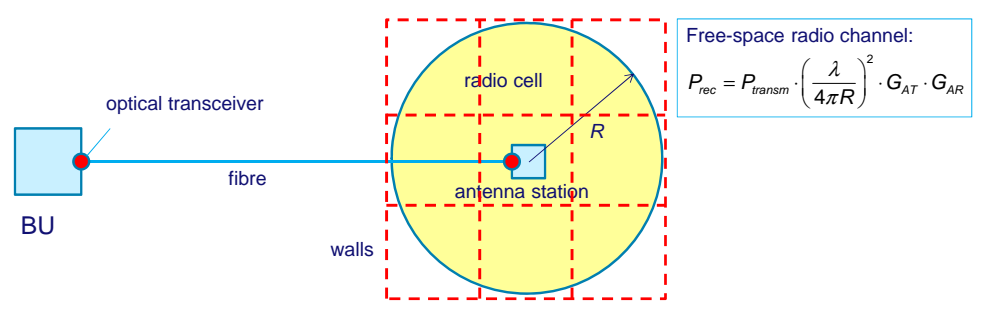

Total power consumed:

$P_{\text {tot, single cell }}=P_{\text {radio }}+P_{\text {optical }}=c \cdot R^{\gamma} \cdot A_{1}^{\sqrt{N}-1} \cdot P_{\text {mob }}+2 \cdot P_{\text {trx }}$

where

- $c$ includes antenna gains and OE signal conversion efficiency

- $N$ is number of rooms

- $A_{1}$ is attenuation factor per wall crossing

- $\gamma$ is path loss exponent ( $\gamma=2$ in free space, $\gamma$ may be up to 4 or more inside buildings)

- $P_{\text {mob }}$ is received radio power needed at mobile device

- $P_{t r x}$ is power needed in optical transceiver
Fibre-fed radio pico-cells

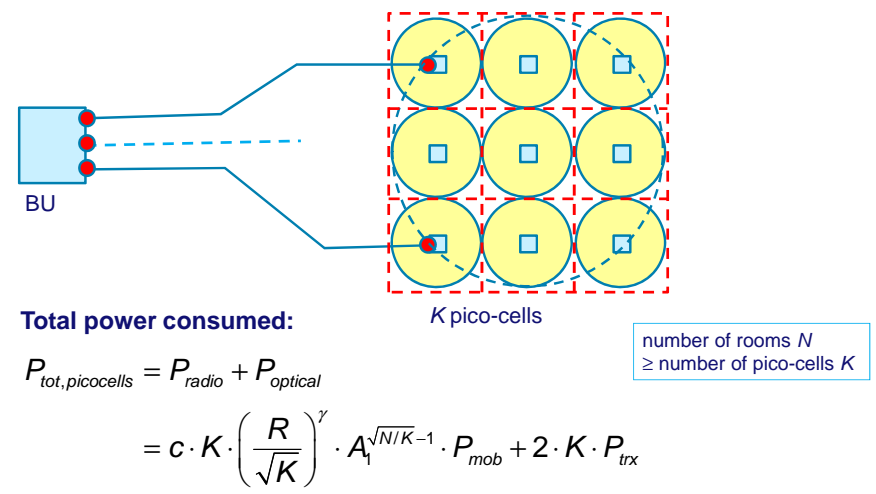

Total power consumption: pico-cells vs. single cell $\frac{P_{\text {tot, picocells }}}{P_{\text {tot, single cell }}}=\frac{K^{1-\gamma / 2}}{A_{1}^{\sqrt{N}-\sqrt{N / K}}}+\frac{2 K \cdot P_{t r x}}{P_{\text {tot, single cell }}}\left(1-\frac{K^{-\gamma / 2}}{A_{1}^{\sqrt{N}-\sqrt{N / K}}}\right)$

is dependent on number $K$ of pico-cells, must be $<1$ for total power saving. For $A_{1}=1$ (no walls), total power consumption is minimum for

$K=\left[\frac{\gamma-2}{2}\left(\frac{P_{s}}{2 P_{t r x}}-1\right)\right]^{2 / \gamma}$

Energy savings by pico-cells
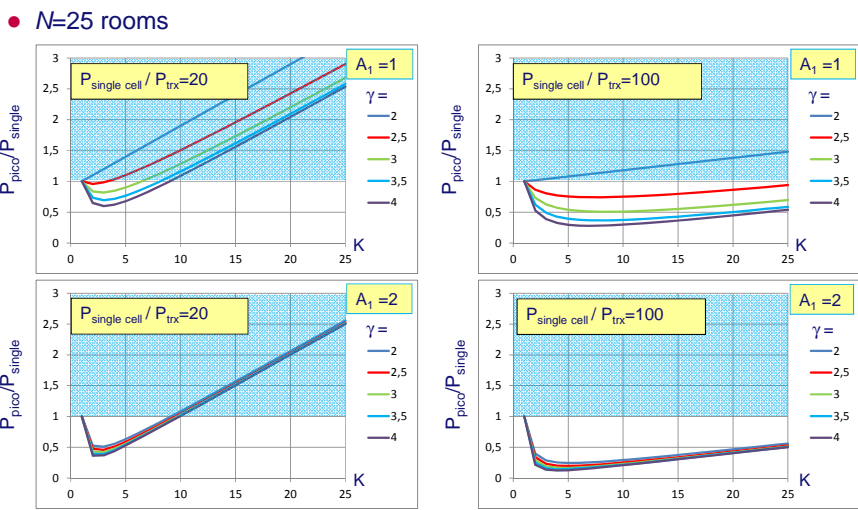

\section{Concluding remarks}

- Radio-over-fiber based pico-cell techniques can improve not only the capacity but also the energy efficiency of wireless networks.

- As long as the number of pico-cells stays below an upper bound, the total power consumption of the network is less than that of a single-cell network

- Total power consumption is minimized by optimizing the number of pico-cells.

- The optimum number of picocells increases and the attainable minimum power consumption decreases when radio path loss exponent increases, wall losses increase, and/or RoF transceiver power consumption decreases. 